\title{
CHANGES IN THE LOGISTICS SYSTEM OF THE POLISH NAVY
}

\section{Mariusz Jankowski 1}

Polish Naval Academy, Faculty of Command and Naval Operations, Śmidowicza 69 Str., 81-127 Gdynia, Poland; e-mail: m.jankowski@amw.gdynia.pl; ORCID ID: 0000-0002-1447-1482

\begin{abstract}
The aim of the article is to show the changes taking place in the structures of logistical support of the Polish Navy, focusing on the changes in the way of supplying ships of the Polish Navy. In recent years, the Polish Navy has undergone many changes in the subject matter, starting from the liquidation of the Logistics of the Polish Navy and the Polish Navy Command, including the Management of Logistics Planning. The changes contributed to the centralization of Logistics, creating the Inspectorate for Armed Forces Support of the Republic of Poland, which focused on the main burden of tasks related to, among others, repairs, modernization and supply of ships. On the other hand, it extends the time of issuing opinions on, for example, the protocols for assessing the technical condition of military equipment (ME), which are the basis for the replacement, repair or further exploitation of the ME.
\end{abstract}

Key words:

logistics support, ME, Inspectorate for Armed Forces Support.

Research article

(C) 2019 Mariusz Jankowski This is an open access article licensed under the Creative Commons Attribution-NonCommercial-NoDerivatives 4.0 license (http://creativecommons.org/licenses/by-nc-nd/4.0/) 


\section{INTRODUCTION}

The Polish Navy is designed to defend the interests of the state in the Polish maritime areas, maritime defence of the coast and participation in the land defence of the coast in cooperation with other types of armed forces as part of a strategic defence operation. In accordance with international obligations, the Navy maintains its capacity to carry out tasks related to safety both in and outside the Baltic Sea region. The main task of the Navy is to defend and maintain the state's maritime communication lines during a crisis and war and to prevent the country's naval blockade. During peacetime, the Navy supports the activities of the Border Guard in the area of sea territorial waters and the exclusive economic zone.

As part of the adjustment of the naval forces of the Republic of Poland to the requirements of the allies, the Navy will possess vessels ensuring active participation in the projection of the joint NATO and the EU forces. The structure of the Navy consists of naval flotillas of ships, earlier by the end of 2013 also the Naval Aviation Brigade, as well as coastal support and security units and training centres [5]. The core of the Polish Naval Forces consists of two flotillas, 3rd Ships Flotilla and 8th Coastal Defence Flotilla consisting of surface vessels, submarines and auxiliary vessels.

Membership of the Republic of Poland in the North Atlantic Treaty Organization (NATO) obliges the Polish Navy to intensify adjustment processes aimed at achieving the required level of standardization in all areas of operation, including the maritime logistics system [3].

In accordance with the ALP-4 (Multinational Maritime Force Logistics) alliance document, the Logistics Doctrine of the Navy DD/4.1 has been developed, which to a large extent is the basis for the development of this article.

The logistical system of the Armed Forces is a complex military organisation. It consist of governing bodies and logistic units and devices linked to each other by a relationship [4]. This system includes the existing naval logistics system. The aim of the logistical security of the troops is, inter alia, to meet their needs in terms of weapons, military equipment, combat and material means for training and combat, and to maintain the personal and technical fitness of the military equipment to carry out its activities.

The effectiveness of operations of navy is determined by a number of factors, ranging from combat and auxiliary ships, the training of crews to problems of operating and using equipment and armaments, as well as security and logistical support for operations. The last factor, often trivialised and undervalued in the past, led to the breakdown of operations and even to the collapse of great world powers. 


\section{LOGISTICS SUPPORT IN THE POLISH NAVY}

Due to the character of the Navy's operations, the logistics support is provided to teams of vessels in coastal units and naval aviation. This is a very complex task and therefore requires coordinated action in the maritime and coastal zones and onshore. It is therefore important to clarify the principles and mechanisms of functioning of particular logistics subsystems and changes that have occurred in recent years [1].

In order to better understand the issues discussed, it is necessary to present the logistics subsystems that were and are currently responsible for the logistics of the Polish Navy.

For decades the Polish Navy's structures included units responsible for logistics, logistics security, logistics support or rear support, as logistics support was previously called.

From 1986 until mid 1994 this task was performed by the Head of Technical Services and Supplies Navy Command (HoTS NC). It consisted of:

- Deputy Chief of Technical Affairs;

- Deputy Chief of Organisational and Mobilisation Affairs;

- Chief of the Technical and Ship's Service;

- Chief of the Service for Fuels and Lubricants;

- Chief of the Communication Service;

- Chief of the Uniformed Service;

- Chief of the Food Service;

- Chief of the Health Service.

Subsequent changes appeared in the Logistics of the MW established in 1994, which was commanded by the Head of Logistics of the Deputy Commander of the Polish Navy - the disposer of the third degree budgetary resources.

Further structural changes took place in the following years in order to improve the management and command system of Logistics related to the development needs of the Polish Navy and the introduction of new ships and equipment, as well as, what is more important, new standards related to interoperability and operations within NATO forces.

During this period, new units were functioning, including essentially the Logistics Staff and a number of technical and supply services. In 2000, the structure of Naval Logistics included, among other things, the following chiefs:

- Deputy Chief - Head of the Shipbuilding, Maintenance and Supply Department;

- Head of Maritime and Aviation Technology; 
- Head of the Materials Services;

- Head of the Health Service, as well as typical financial and material planning, settlements, contracts and staff units ensuring proper functioning of Logistics and support for the commander of the Polish Navy.

In the meantime, the Marine Technology Headquarters of the Ministry of National Defence operated, dealing with tactical, technical and economic analyses, creating requirements, concluding contracts for the supply of new ships, development, design, supervision over the construction and modernization of ships, development work and introduction of new types of equipment and ships to the Polish Armed Forces, including the Polish Navy.

Subsequently, for a short period of time, a non-regular Head of Planning and Development of the Navy, separated from the Navy Command, was functioning, which created the development of new technology and preparation of the Navy for integration with the allied forces.

Subsequent changes occurred in 2005. This structure included the following posts:

- Deputy Chief - Chief of Logistics Planning N-4;

- Chief of Ships' Construction and Exploitation;

- Chief of Material Services;

- Chief of Aviation and Maritime Technology;

- Chief of the Military Infrastructure and Environmental Protection Department.

The first step towards the complete liquidation of Logistics in the Naval Command structures was the formation in 2007 of the Inspectorate for Armed Forces Support (IfAFS) of the Republic of Poland. In its structures the Chief of Maritime Technology was appointed. This resulted in the liquidation of Naval Logistics and taking over the tasks by IfAFS, keeping the Logistics Planning Department N-4 in the Command. The Inspectorate for Armed Forces Support became the disposer of the second degree budgetary resources and, to a large extent, the decision maker of their division into the needs of subordinate units. The function of the Management of Logistics Planning was rather consultative and opinion-making.

The presented transformation of logistics was forced by the adaptation of our logistics system to the logistics systems of NATO countries, where these matters are more precisely regulated by allied doctrines. Poland, a signatory of the North Atlantic Treaty since 12 March 1999, has been obliged to adapt to its order. The presented changes have also led to changes on the lowest tactical level. In the military units the Heads of Logistics were liquidated and replaced by Deputy Chief of Staff 
for support matters. Currently, the Polish Naval Logistics system, if it can still be called so, has entailed a number of problems, especially at the tactical level. In order to explain the current problems faced by the equipment explorers, among others, on navy ships, in the further part of the article the rules of material management of the ship will be presented.

\section{RULES OF SUPPLYING, REPAIRING AND EXCHANGING MILITARY EQUIPMENT IN THE POLISH NAVY}

The catalogue of standards for the operation of military equipment and devices in the Polish Navy contains the target standards of operation, repair intervals of ships (including the division into types of repairs) as well as repair intervals of other equipment and weaponry used on ships. The catalogue allows proper planning of repairs as well as planning the purchase of new equipment after the withdrawal of the obsolete one.

The Catalogue is not the only document that regulates the principles of ME exploitation, there are a number of other studies, decisions, guidelines and orders which regulate the proper exploitation of the entrusted property. Documents are helpful, however, in reality it is very difficult to adhere strictly to the set rules. There are problems of economic nature and in times of crisis it is often the case that standards are extended in a manner that is as lawful as possible, but in some cases leading to a technological collapse of the used ME.

The correctness and observance of the rules is ensured by the institutions established for this purpose, which were divided according to the logistics doctrine into 4 logistics levels: level I - tactical (ship), level II — tactical (flotilla), level III operational (The Inspectorate for Armed Forces Support) and level IV - strategic (Ministry of National Defence) [3]. The Inspectorate for Armed Forces Support is a central executive logistics institution created in order to provide comprehensive logistics support for all types of Armed Forces - based on the needs generated by the Military Units. The Inspectorate for Armed Forces Support as an disposer of second degree budgetary resources in selected groups of the ME performs the tasks of the administrator and the central logistical departments of the Armed Forces. In the field of armaments and naval equipment, the function of the administrator is performed by organizational units subordinated to the Commander-in-chief of the Polish Navy [3]. 


\section{Main task of MEGestors and Central logistics departments}

In his decision No. 435/MON of 24 December 2013, the Minister of National Defence defined the functions of the gestors and central logistic departments of military equipment in the Ministry of National Defence. Gestor is a unit or organizational unit of the Ministry of National Defence, as well as an internal unit, responsible for defining the directions of development of the European Armed Forces in the Polish Armed Forces and for organizing the process of implementation and determining the processes of exploitation (including combat use) and withdrawal of a specific type (group) ME. The tasks of the gestors include [2]:

- knowledge of the quantitative and qualitative status and prospects for the use of weapons and military equipment, including and using information from the central logistics department;

- determining the directions of development of the ME as well as the principles of its combat use;

- participating in the development of initial tactical and technical assumptions for new types of ME to be obtained by means of development or implementation work;

- taking decisions on the decommissioning of single full-time ME, which is not common equipment, by approving applications of the appropriate central logistics department;

- participation in the performance of the tasks of the acquisition, operation and withdrawal of the ME system in accordance with the rules set out in other regulations;

- defining operational and technical requirements for common-use equipment planned for purchase, in order to include in the contract documents the essential terms of the contract.

Central logistics departments (CLDs) is a department or organisational unit of the Ministry of Defence and an internal department responsible for organising the operational processes and training of technical specialists for specific types of ME. The CLDs tasks include [2]:

- maintaining a collective database on the quantity and quality of a specific ME in the Ministry of National Defence;

- cooperation with ME administrators in the scope of defining the perspectives of use and modernization needs of the ME as well as ongoing exploitation and military research;

- development of principles and standards of ME logistics security including operational standards and normative documents;

- participation in the organisation of training on the use of ME by ME administrators;

- planning and organizing the ME distribution system in agreement with ME administrators; 
- planning and organising the training of specialist logistics personnel and technical specialists for specific types (groups) of ME;

- planning ME repairs and defining technical requirements for the ME planned to be repaired;

- managing and supervising subordinate maintenance and repair systems and procurement;

- management of military forms and printed matter;

- identifying ways to manage the ME that is being phased out and cooperation with the Military Property Agency in this respect;

- issuing opinions on ME exploitation documentation.

\section{Circulation of the ME Technical Condition} Assessment Protocol

A technical condition asessment protocol (TCAP) is drawn up in several cases. It is the base after a positive opinion for further operation of the ME as well as for replacement of the equipment that is inoperative, worn out, or intended for repair. Today, after logistics changes in the Polish Navy, the main problem is the time of TCAP circulation. Fig. 1 shows a schematic document circulation at the time when Polish Navy logistics still existed. Fig. 2 shows the current time after the introduction of the Inspectorate of Polish Armed Forces Support.

It is not difficult to notice that the time of decision making has increased significantly taking up to four months in some cases.

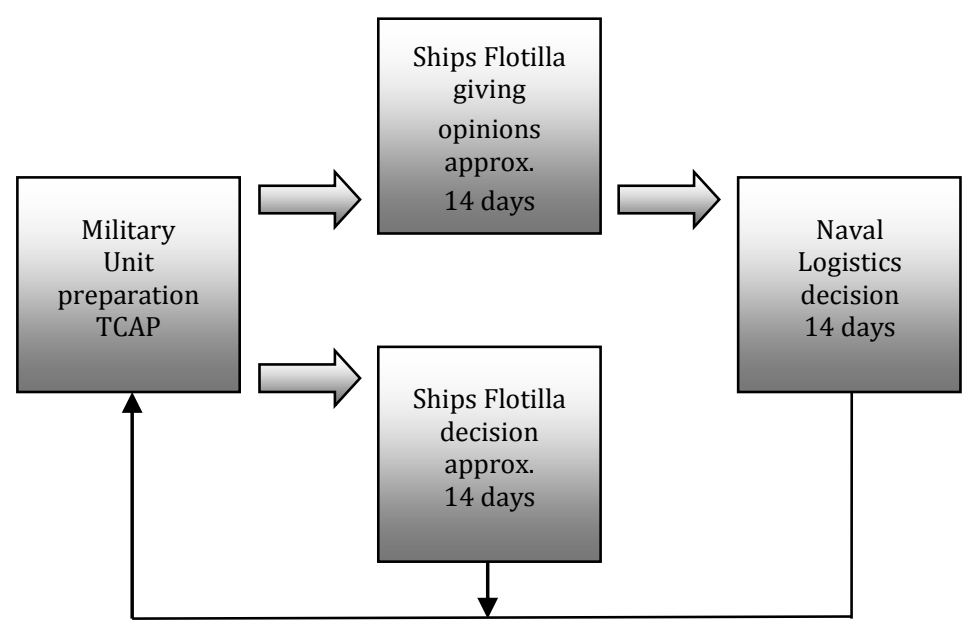

Fig. 1. TCAP circulation during the existence of Navy Logistics 


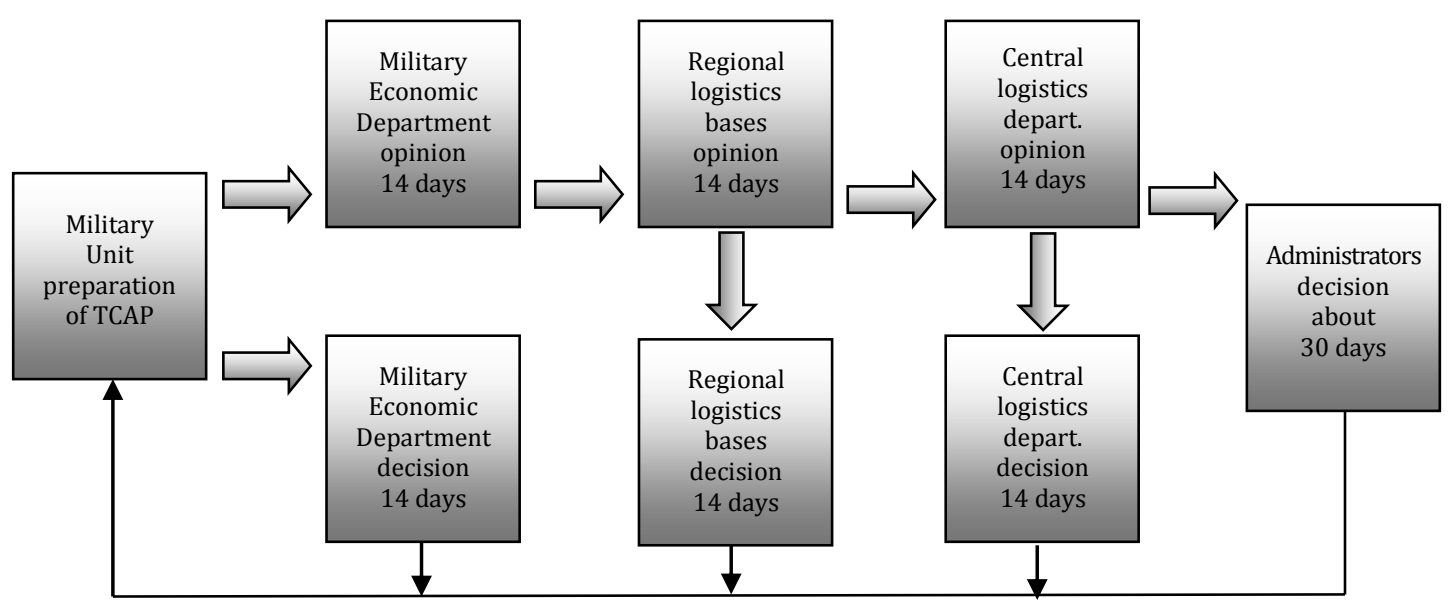

Fig. 2. TCAP circulation after changes

From the practical point of view of the ME user, problems begin at this point as it is the user who is responsible for creating a technical condition assessment protocol of the equipment and armament and he is responsible for observing the standards and timeframes. Since the liquidation of the Navy's logistics TCAP circulation has significantly increased in time, leading to a long wait for acceptance or approval.

The commander of a military unit appoints a commission which prepares appropriate technical condition assessment protocols concerning e.g. prolongation of the service life or withdrawal and replacement of obsolete equipment. The military economic departments, units (MED), in the case of the Polish Navy, the Military Port Commands (MPC), are the first recipients of these protocols.

After the opinion is issued, TCAPs are sent to the Regional Logistics Bases (RLB). Then, after the decision is made, they are sent back to the user, but in case of the opinion they are sent to the Central Logistics Departments, whose rights are both to give opinions as well as to make decisions. The analogy is repeated as in the case of RLB. The last level and at the same time the main decision maker is the equipment administrator. In case of non-acceptance, the protocols return to the sender with guidelines to be followed for reconsideration, practically possible from each level. Maintaining the principles of staff work and strict adherence to the deadlines for processing applications, the time needed for the opinion, the decisions of the responsible institutions which should facilitate the process, make it rather difficult. The seemingly trivial problem of replacing ME with a new one is often the reason for malfunction and, consequently, the inability of the ship to carry out tasks. 


\section{CONCLUSIONS}

To sum up, one question needs to be asked very clearly, whether the liquidation of the Polish Navy Logistics and an attempt to adapt the logistics system to the 'Western' model brings the assumed benefits.

Centralisation of the logistics system has resulted in the division of competences into various decision-making authorities: CLD, Gestors, the Inspectorate for Armed Forces Support, which results in an extended and often incoherent decision-making process. Each of these institutions often issues their opinions on the equipment used and the documents circulate between them for several months.

A perfect solution that would greatly facilitate the circulation of information between the ME user and the central authorities responsible for logistics support of the Polish Navy would be to create a program with a database. The database, as it was in the past, could contain all kinds of information related to the equipment used, the equipment in the warehouses. Responsible persons at all levels could enter information to update the database. The circulation of documents between the user and the CLD using such a programme would significantly shorten the time taken to process commission proposals. The program should have an option to check information on disposable and durable materials.

The modernization of ships and vessels of the Navy has introduced many new equipment and various mechanisms. As a result, new solutions, e.g. power generators, require an appropriate number of parts, which in the process of exploitation in a natural way, are used up. Users repeatedly report problems with the timely delivery of such parts or their insufficient number. The database allows the user to report their needs in good time, so that material services can plan and expand their assortment with additional equipment and spare parts.

During my thirteen years' service on board ships, I was responsible for proper operation in the engineering department and in the ship's operation division later. The problems mentioned above also concerned me on a daily basis. An important remark is the fact that during the existence the Polish Navy Logistics, the circulation of documents was much shorter. The Commission prepared appropriate proposals for extending the inter montage service and the decision was often made at the level of the tactical unit which is the flotilla of ships. In the case of consultations or opinions, such conclusions ended at the level of the Polish Navy Command, strictly speaking the Polish Navy Logistics. Changes in the logistics system were mainly aimed at separating military and economic functions from operational and training functions in military budgetary units. As we note, changes do not always go in the right direction, but the structures that were once so well developed were justifiable. 
Another more extensive task of users is to draw up lists of renovation works in particular ship departments, which are then collected and sent to the CLD, where the following take place: verification, making comments, deleting unfounded positions or not beneficial from the point of view of implementing new technologies or ordinary economy. As a consequence, after users's acceptance, the ship is planned for renovation. Preparing lists of renovation works takes time, therefore lists should be prepared two years before the planned renovation. It is recommendable to prepare inventories resulting from equipment faults, failures and sometimes simply to improve mechanisms or devices during their exploitation.

A condition for the development of lists of renovation works in such a way that they are legible, comprehensive and clearly specify the renovation needs of Polish Navy ships, to a large extent depends on several factors. They include knowledge in addition to the experience of personnel creating lists of renovation works, time, and access to technological novelties that can be used as newer solutions to existing devices and access to a database of spare parts that are on stock levels and depots. Chiefs of Logistics with enormous potential (knowledge and experience), the recruitment of which was often out of the mechanics officers characterized by long term service on the ship is irretrievably lost.

The presented problems are a drop in the ocean of matters that surround ME users. Perhaps this publication will inspire someone to investigate the subject, basing their conclusions on evidence, research, experience of others. It is true that the topic is worth discussing at a higher level, not only at a tactical level whose aim should be to develop an optimal (why not the best?!) management structure and to create procedures for system operation in the structure of logistics army forces in terms of 'cost-effect', which is a standard in other allied navies. Issues that require a lot of time and energy, especially in the scope of operations and planning related to the introduction of new ships and new ME to the line, is the construction of ILS - Integrated Logistics System from the stage of making a decision on the construction of a specific type of ship or auxiliary vessels with regard to the need to define operating standards, budget and the entire new planned logistics infrastructure, including coastal and organizational.

\section{REFERENCES}

[1] Bursztyński A., Logistyka Marynarki Wojennej, Publ. Akademia Marynarki Wojennej, Gdynia 2009 [Polish Navy logistics — available in Polish]. 
[2] Decyzja nr 435/MON z dnia 24 grudnia 2013 r. w sprawie określenia funkcji gestorów i centralnych organów logistycznych sprzętu wojskowego w resorcie obrony narodowej [Decision No. 435/MON of 24 December 2013 on the definition of the functions of the gestors and the central logistic department for military equipment in the Ministry of Defence - available in Polish].

[3] Doktryna logistyczna Marynarki Wojennej RP DD 4.1, Dowództwo MW, Gdynia 2009 [Polish Navy logistics doctrine DD 4.1 - available in Polish].

[4] Ficoń K., Modelowanie infrastruktury wojskowych systemów logistycznych, 'Zeszyty Naukowe AON', 2000, No. 3(40), pp. 137-152 [Modelling of military logistic systems infrastructure, — available in Polish].

[5] Strategia Obronności RP, pkt 106, Warszawa 2009 [Defence Strategy of the Republic of Poland, point 106 - available in Polish].

\section{ZMIANY W SYSTEMIE LOGISTYCZNYM MARYNARKI WOJENNEJ RP}

\section{STRESZCZENIE}

W artykule pokazano zmiany zachodzące w strukturach zabezpieczenia logistycznego Marynarki Wojennej Rzeczypospolitej Polskiej, koncentrując się głównie na zmianach w sposobie zaopatrywania okrętów Marynarki Wojennej RP. W ostatnich latach nastąpiła tu duża reorganizacja. Rozwiązano Dowództwo MW RP, likwidując Logistykę MW RP oraz Zarząd Planowania Logistycznego, a stworzono Inspektorat Wsparcia Sił Zbrojnych RP, który skupił na sobie ciężar zadań związanych między innymi z remontami, modernizacją i zaopatrywaniem okrętów. Spowodowało to wydłużenie czasu opiniowania protokołów oceny stanu technicznego sprzętu woskowego (SpW), które są podstawą do wymiany, remontu lub dalszej eksploatacji SpW.

Słowa kluczowe:

zabezpieczenie logistyczne, SpW, Inspektorat Wsparcia Sił Zbrojnych RP.

Article history

Received: $\quad 08.04 .2019$

Reviewed: 15.05.2019

Revised: $\quad 13.06 .2019$

Accepted: 14.06 .2019 